\title{
Wanna Buy a Ringtone Real Cheap?
}

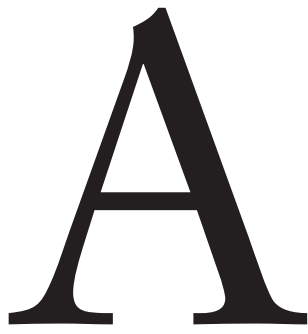

$s$ I read the daily news feeds from the digital realm, I am often struck by the casual absurdity of our laws and regulations regarding ownership of intellectual property. In the words of the ACLU's Christopher Hansen as quoted in this month's net Worker cover story, "Patently False," federal courts have recently interpreted patent laws "so broadly as to make it possible to patent anything," no matter how obvious or abstract. And copyright laws have been stretched to the point where big media companies, especially, seem comfortable with the idea that customers should never actually own the digital content they purchase. Any change of venue-from laptop to television to iPod—and typically we are asked to pay again.

Of course, it gets worse: I recently received a pitch for a single 30 -second ringtone that gently asked me to schedule annual payments for the rest of my life. It would have been funny if it weren't so troubling (actually it was funny) and so contrary to what copyright laws were originally intended to do: promote the creation of new works by allowing authors to reasonably profit from the sale of existing works.

In the world of computer software, patents have been granted for basic, widely shared ideas ever since the misguided State Street ruling of 1998. But it may actually be time for common sense to prevail. The Federal Circuit Court of Appeals has agreed to hear the crucial Bilski patent case, and preliminary signs suggest that the court is warming to the idea of repairing the U.S. patent system via an enlightened ruling. If the result is that software patents disappear entirely, they will remain protected, in a different way, by copyright. Perhaps the coming "regime change" in Washington will inspire our public officials to tackle copyright issues next. Until then, I know I'll stay busy scheduling all those reasonable annual payments.

Ken Korman, Executive Editor
netWorker

is a quarterly publication of ACM,

The Association for Computing Machinery

PUBLICATIONS OFFICE: ACM, 2 Penn Plaza, Suite 701, New York, New York 10121-0701, +1-212-869-7440,

FAX: +1-212-869-0481

Group Publisher: Scott Delman

Executive Editor: Ken Korman Managing Editor: Denise Doig Art Director: Andrij Borys

Production Manager: Lynn D'Addesio-Kraus Media Sales: Jonathan Just

Contributing Editors:

Books: Michele Tepper

(mtepper@panix.com)

Business the 8th Layer: Lynn Greiner

(lynng@ca.inter.net)

Net News: Alan Zeichick

(zeichick@acm.org)

Putting it Together: Win Treese

(treese@acm.org)

Editorial advisory board:

Grady Booch

Bran Ferran

Jim Gemmell

David S. Isenberg

Jakob Nielsen

Donald A. Norman

Daniel Rosenberg

ACM Advertising Department

2 Penn Plaza, Suite 701

New York, NY 10121-0701

(212) 869-7440; Fax (212) 869-0481

Director of Media Sales:

Jonathan Just

email: jonathan.just@acm.org

nefWorker (ISSN 1091-3556) is published four times a year in March, June, September, and December by the Association for Computing Machinery, Inc., 2 Penn Plaza, Suite 701, New York, NY 10121-0701.

Periodical class postage paid at $\mathrm{New}$ York, NY 10001, and at additional mailing offices. Printed in the U.S.A.

POSTMASTER: Send address changes to netWorker, ACM, 2 Penn Plaza, Suite 701, New York, NY 10121-0701. 


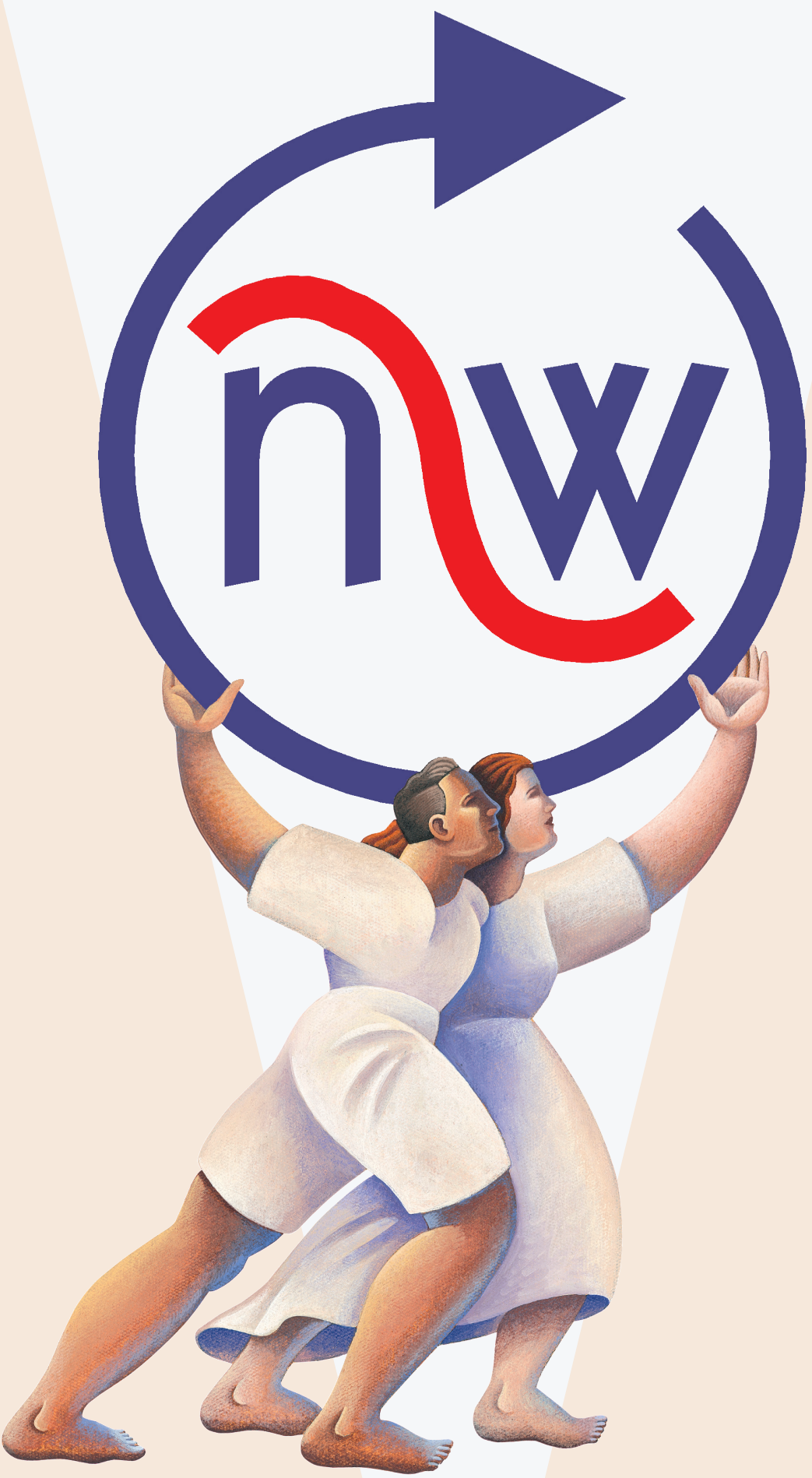

netWorker

is a quarterly publication of ACM,

The Association for Computing Machinery

Director of Publications: Mark Mandelbaum

Publications board: Co-chairs:

Ronald F. Boisvert and Mary Jane Irwin

Gul Agha, Robert B. Allen, Michel

Beaudouin-Lafon, Adolfo Guzman-Arenas,

Wendy Hall, Carol Hutchins, Keith

Marzullo, M. Tamer Ozsu, Holly Rushmeier, Mary Lou Soffa

Subscriptions: Annual cost to ACM members: $\$ 54.00$, student members: $\$ 49.00$, individual nonmembers: $\$ 105.00$ nonmember institutions: $\$ 105.00$

Single copies are $\$ 13.00$ to members, $\$ 20.00$ to nonmembers. Please send orders prepaid plus $\$ 7.00$ for domestic shipping and handling ( $\$ 8.00$ for foreign) to $A C M$ Order Dept., P.O. Box 11414, New York NY 10257 or call +1-212-626-0500. For credit card orders, call +1-800-342-6626

Order personnel available 8:30-4:30 EST. After hours, please leave message and order personnel will return your call.

Change of address: acmcoa@acm.org

For other services, questions, or information: acmhelp@acm.org

\section{http://www.acm.org/networker}

\section{Copyright (C) 2008 by Association for}

Computing Machinery, Inc. (ACM). Permission to make digital or hard copies of part or all of this work for personal or classroom use is granted without fee provided that copies are not made or distributed for profit or commercial advantage and that copies bear this notice and full citation on the first page. Copyright for components of this work owned by others than ACM must be honored. Abstracting with credit is permitted. To copy otherwise, to republish, to post on servers, or to redistribute to lists, requires prior specific permission and/or fee. Request permission to publish from: Publications Dept., ACM, Inc. Fax +1-212-869-0481 or email permissions@acm.org

For other copying of articles that carry a code at the bottom of the first or last page or screen display, copying is permitted provided that the per-copy fee indicated in the code is paid through the Copyright Clearance Center, 222 Rosewood Drive, Danvers, MA 01923, + 1-978-750-8400, $+1-978-750-4470$ (fax). 